\title{
Monacha cartusiana (Gastropoda: Hygromiidae) in South Bohemia
}

\author{
Pavel Pechi ${ }^{1,2} \&$ Hana Pechová ${ }^{1}$ \\ ${ }^{1}$ Faculty of Science, University of South Bohemia, Branišovská 31, CZ-37008 České Budějovice, Czech Republic, e-mail: \\ Muravji2@yahoo.com,hzajicova@centrum.cz \\ ${ }^{2}$ National Museum, Department of Zoology, Václavské náměstí 68, CZ-11579 Praha 1, Czech Republic
} Pech P. \& Pechová H., 2009: Monacha cartusiana (Gastropoda: Hygromiidae) in South Bohemia. - Malacologica
Bohemoslovaca, 8: 28. Online serial at $<$ http://mollusca.sav.sk> 10-August-2009.

The first record of non-indigenous expanding mollusc species Monacha cartusiana (O.F. Müller, 1774) is reported - the species was found on a dam of a coal-ash settling basin near České Budějovice.

Key words: Monacha cartusiana, Czech Republic, new finds, spreading

\section{Introduction}

Monacha cartusiana (O.F. Müller, 1774) (Gastropoda: Hygromiidae) is a west and south European species. In the Czech Republic, M. cartusiana was formerly relatively rare and scarce distributed, restricted to several isolated parts of country (LožEK 1956); recently, M. cartusiana have expanded (MíkovcovÁ \& JuŘIČKOVÁ 2008) and can occur in artificial habitats (JUŘIČKOVÁ \& KUČERA 2007).

\section{Locality and methods}

The coal-ash settling basin is situated on the edge of the town of České Budějovice, between the parts of České Budějovice, Nové Hodějovice, and Stará Pohůrka, a part of the village Srubec (7053, GPS $\left.48^{\circ} 57^{\prime} \mathrm{N}, 1^{\circ} 30^{\prime} \mathrm{E}\right)$. The dam is terraced. Three biotopes can be found on the dam: young pine-wood, mesic and dry meadows on slopes and mesic and wet meadows on the terraces. The basin itself consists of the water surface, large, partly mowed reed bush and a small birch grove.

Several trips were made to the location in 2009. The material was obtained via hand-collecting. The shells are deposited in the collection of both authors.

\section{Results}

More than twenty shells (both adult and juveniles) and several live individuals of $M$. cartusiana were found on the dam. All were situated on meadow slopes and at its base. It is the first record of this species in South Bohemia (Míkovcová, pers. comm.). Besides M. cartusiana, the following species were found: Arianta arbustorum (Linné, 1758), Cepaea hortensis (Müller, 1774), Cepaea nemoralis (Linné, 1758), and Succinella oblonga Draparnaud, 1801 on dam, Zonitoides nitidus (Müller, 1774), Perpolita hammonis (Alder, 1830), and Punctum pygmaeum (Draparnaud, 1801) in reed bush.

\section{Discussion}

The population of $M$. cartusiana near České Budějovice is isolated. Recently, the mapping of the distribution M. cartusiana in the Czech Republic is proceeding (http://www. biolib.cz; Míkovcová \& JuřıčKovÁ 2008). The nearest locality, where M. cartusiana has been found, is Beroun in central Bohemia (http://www.biolib.cz). On the other hand, M. cartusiana is relatively abundant in Austria (e.g. FrANK 1986); possibly, the population of M. cartusiana near České Budějovice is connected to the Austrian populations rather than the $\mathrm{Czech}$ ones.

\section{Acknowledgement}

We are thankful to A. Míkovcová, L. Juřičková, and L. Dvořák for valuable comments.

\section{References}

http://www.biolib.cz/ (cited 19 Jul 2009)

Frank C., 1986: Zur Verbreitung der rezenten schalentragenden Land- und Wassermollusken Österreich. - Linzer biologische Beiträge, 18: 445-526 (in German).

JUŘIČKOVÁ L. \& KUČERA T., 2007: Land snail assemblage patterns along motorways in relation to environmental variables. - Contributions to Soil Zoology in Central Europe II, TAJOvsKÝ K. SchlaghamerskÝ J. \& PižL V. (eds.). ISB BC AS CR, v.v.i., České Budějovice, pp. 75-78.

LožEK V., 1956: Klíč československých měkkýšů. - SAV, Bratislava, 437 pp. (in Czech).

MíkovcovÁ A. \& JuŘıčKovÁ L., 2008: Hledá se tmavoretka bělavá [Monacha cartusiana is wanted]. - Živa 2/2008: 73. (in Czech). 